JURNAL MATEMATIKA. STATISTIKA \& KOMPUTASI

https-//journal unhas.acid/indexphp/jmsk/index

Vol. 17, No. 2, 325-338, January, 2021

DOI: 10.20956/jmsk.v17i2.12057

\title{
Bicluster CC Algoritm Analysis to Identify Patterns of Food Insecurity in Indonesia
}

\author{
Analisis Bicluster Algoritma CC untuk Mengidentifikasi Pola Rawan \\ Pangan di Indonesia
}

\author{
Raditya Novidianto $^{1^{*}}$, Rini Irfani ${ }^{*}$
}

\begin{abstract}
Indonesia is known as an agricultural country. This means that most of the population work in the agricultural sector related to food. However, food insecurity still occurs in Indonesia. With the COVID-19 pandemic, the Food and Agriculture Organization (FAO) stated that there was a threat of food scarcity which had an impact on food insecurity conditions. This would undermine the second goal of the SDGs, which is to end hunger and create sustainable agriculture. The purpose of this study was to determine the spatial pattern of food insecurity in each province in Indonesia using the bicluster method. The data used are data from Susenas and Sakernas by BPS in 2019. Several studies show that the bicluster method with the $\mathrm{CC}$ algorithm shows that each province group has a different characteristic pattern. In the bicluster approach, the researcher runs parameter tuning to select the best parameter based on the Mean Square Residual in Volume (MSR / V). The CC algorithm tries to get a bicluster with a low MSR value, therefore the best parameter is the one that produces the smallest MSR / V value, in this study the smallest MSR / V is 0,01737 with $\delta=0,01$. The application of the $\mathrm{CC}$ biclustering algorithm to the food insecurity structure in Indonesia results in 5 bicluster. Bicluster 1 consists of 15 provinces with 8 variables, Bicluster 2 consists of 10 provinces with 5 variables, Bicluster 3 consists of 3 provinces with 7 variables, Bicluster 4 consists of 4 provinces with 4 variables and Bicluster 5 consists of 2 provinces with 5 variables. Biculster 4 represents a cluster of food insecurity areas with the characteristics of the bicluster P0, P1, P2 and calorie consumption of less than $1400 \mathrm{KKAL}$.
\end{abstract}

Keywords: Biclustering, CC, Algoritm, Food Insecurity.

\begin{abstract}
Abstrak
Indonesia dikenal sebagai negara agraris. Artinya, sebagian besar penduduknya bekerja di sektor pertanian yang berkaitan dengan pangan. Namun kerawanan pangan masih terjadi di Indonesia. Adanya pandemi COVID-19, Organisasi Pangan dan Pertanian (FAO) menyatakan adanya ancaman kelangkaan pangan yang berimbas kepada kondisi rawan pangan. Hal tersebut akan mengganggu tujuan kedua SDGs yaitu untuk mengakhiri kelaparan dan menciptakan pertanian berkelanjutan. Tujuan penelitian ini untuk mengetahui pola kerawanan pangan di setiap Provinsi di Indonesia secara spasial dengan menggunakan metode bicluster. Data yang digunakan adalah data dari Susenas dan Sakernas oleh BPS tahun 2019. Beberapa hasil studi menunjukkan bahwa dengan metode bicluster dengan algoritma CC terlihat setiap kelompok Provinsi memiliki pola karakteristik yang

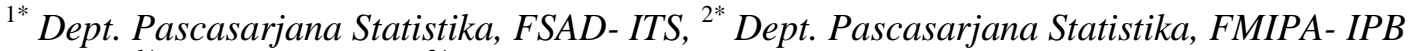
Email : ${ }^{1^{*}}$ radit@bps.go.id, ${ }^{2 *}$ rini.irfani@bps.go.id

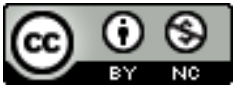

This work is licensed under a Creative Commons Attribution-NonCommercial 4.0 International License 


\section{Raditya Novidianto, Rini Irfani Jurnal Matematika, Statistika \& Komputasi}

berbeda-beda. Pada pendekatan bicluster, peneliti menjalankan tuning parameter untuk memilih parameter terbaik berdasarkan Mean Square Residual dalam Volume (MSR / V). Algoritma CC berusaha mendapatkan bicluster dengan nilai MSR yang rendah, oleh karena itu parameter yang terbaik adalah yang menghasilkan nilai MSR/V terkecil, dalam penelitian ini MSR/V terkecil 0,01737 dengan $\delta=0,01$. Penerapan algoritma CC biclustering pada struktur kerawanan pangan di Indonesia menghasilkan 5 bicluster. Bicluster 1 Terdiri dari 15 provinsi dengan 8 variabel, bicluster 2 terdiri dari 10 provinsi dengan 5 variabel, bicluster 3 terdiri dari 3 provinsi dengan 7 variabel, bicluster 4 terdiri dari 4 provinsi dengan 4 variabel dan bicluster 5 terdiri dari 2 provinsi dengan 5 variabel. Biculster 4 merepresentasikan cluster daerah rawan pangan dengan karakteristik pembentuk bicluster yaitu P0, P1, P2 dan konsumsi kalori kurang dari 1400 KKAL.

Kata kunci: Biclustering, CC, Algoritma, Rawan Pangan.

\section{Pendahuluan}

Indonesia sering dikenal dengan sebutan negara agraris karena sebagian besar penduduknya memiliki mata pencaharian sebagai petani [13]. Sebagian besar petani di Indonesia merupakan petani tanaman pangan, sehingga akses terhadap pangan cukup mudah. Namun beberapa data mengungkapkan bahwa kasus rawan pangan di Indonesia masih cukup besar. Tahun 2018 di Indonesia memiliki prevalensi penduduk dengan status rawan pangan sedang atau berat sebesar 6,86 persen turun 1,42 persen ditahun 2019 menjadi sebesar 5,42 persen. Selain itu terdapat sekitar 7,95 persen prevalensi penduduk Indonesia di tahun 2018 mengalami ketidakcukupan pangan serta terdapat sekitar 22,26 persen kelompok pengeluaran kuintil I yang asupan kalorinya dibawah 1400 KKAL, sehingga hal tersebut dijadikan sebuah indikator untuk melihat target tujuan 2 SDGs di Indonesia [3]. Data tersebut mengindikasikan masih besarnya kasus rawan pangan di Indonesia, hal tersebut perlu diidentifikasi dan diantisipasi terlebih adanya pandemi Corona Virus Disease 2019 (COVID-19) yang sedang melanda di berbagai negara di dunia.

Indikator 2.1.2 SDGs menunjukkan bahwa salah satu pengukuran keberhasilan mengatasi kerawanan pangan digunakan variabel konsumsi kalori kurang dari 1400 KKAL [4]. Pengukuran rawan pangan secara mikro juga dapat dilakukan dengan menggunakan variabel kemiskinan, kondisi perumahan, status bekerja anggota rumah tangga, kebiasaan merokok, pengeluaran rumah tangga, demografi rumah tangga, status bencana, status daerah dan ketenagakerjaan bidang pertanian [10]. Di sisi lain, masalah kesehatan berhubungan erat dengan kondisi rawan pangan, dengan adanya permasalahan terhadap kesehatan berawal dari adanya kasus rawan pangan [9]. Pendekatan tak langsung biasa dilakukan dengan menggunakan variabel makro seperti Gross Domestic Product (GDP), gini rasio, rata-rata kematian bayi untuk melihat fenomena yang menunjukkan bahwa rawan pangan memiliki asosiasi yang kuat dengan kondisi kemiskinan pada suatu negara [8].

Badan Ketahanan Pangan menyusun sebuah proxy pendekatan menghitung indeks komposit melalui variabel rawan pangan atau biasa yang disebut indikator Food Security and Vulnerability Atlas (FSVA) yang dijadikan proxy mengukur tingkat kerawanan pangan suatu daerah. Pengukurannya menggunakan 12 indikator yaitu konsumsi kalori perkapita, persentase penduduk di bawah garis kemiskinan, proporsi pengeluaran makanan, persentase penggunaan rumah tangga tanpa akses listrik, rata-rata lama sekolah, persentase rumah tangga tanpa akses ke air bersih, rasio jumlah penduduk, persentase balita dengan tinggi badan di bawah standar, Angka Harapan Hidup $(\mathrm{AHH})$, bencana alam terkait iklim, variabilitas curah hujan dan rata-rata hilangnya produksi tanaman pangan [1]. Indikator FSVA 2019 menunjukkan terdapat 76 kabupaten/kota (71 kabupaten dan 5 kota) yang rentan rawan pangan di Indonesia.

COVID-19 telah ditetapkan sebagai pandemi oleh World Health Organization (WHO) tanggal 11 Maret 2020, sehingga dalam penanganannya diperlukan cara khusus. Beberapa negara termasuk Indonesia telah menerapkan beberapa skema agar penularan COVID-19 dapat dikendalikan. Salah 


\section{Raditya Novidianto, Rini Irfani Jurnal Matematika, Statistika \& Komputasi}

satu kebijakan pengendalian COVID-19 di Indonesia yaitu dengan melakukan PSBB (Pembatasan Sosial Berskala Besar), Work From Home (WFH), School From Home (SFH), social distancing, pemberlakuan protokol kesehatan di fasilitas-fasilitas umum seperti kendaraan umum, perkantoran dan lain sebagainya. Kebijakan tersebut pasti memiliki dampak terhadap indikator strategis secara makro di Indonesia. BPS melaporkan bahwa pertumbuhan ekonomi Indonesia mengalami resesi pada kuartal III-2020 minus 3,49 persen (year on year/yoy) [4]. Jumlah pengangguran dan jumlah penduduk miskin juga mulai meningkat akibat adanya pandemi. BPS mencatat adanya kenaikan persentase pengangguran yaitu sebesar 4,94 persen di bulan Februari 2020 menjadi 7,07 persen di bulan Agustus 2020. Senada dengan itu, persentase penduduk miskin mengalami kenaikan dari bulan September 2020 sebesar 9,22 persen menjadi 9,78 persen [5]. Indikator-indikator tersebut merupakan pemicu adanya rawan pangan yang terjadi di saat pandemi berlangsung.

Pandemi COVID-19 tentunya berpengaruh secara signifikan terhadap kekurangan pangan sehingga dampaknya pada kondisi rawan pangan dan kenaikan harga pangan [14]. Keberadaan kasus rawan pangan menunjukkan bahwa perlunya perhatian khusus bagi pemerintah dalam penanganan kasus tersebut. Dalam mewujudkan tujuan kedua SDGs yaitu mengakhiri kelaparan, mencapai ketahanan pangan dan meningkatkan gizi serta mempromosikan pertanian yang berkelanjutan pada tahun 2030, maka perlu adanya strategi khusus agar rawan pangan di masa pandemi COVID-19 tidak semakin parah. Cara mengidentifikasi pola variabel penyebab terjadinya rawan pangan yaitu melalui analisis bicluster algoritma Cheng dan Chruch (CC) untuk melihat karakteristik setiap daerah berdasarkan kesamaan peubah bebas dari rawan pangan.

Teknik analisis cluster yang umumnya digunakan adalah metode cluster satu arah. Metode tersebut hanya mempertimbangkan nilai dari setiap obsevasi yang mirip satu sama lain tanpa mempertimbangkan nilai dari setiap observasinya [12]. Pada proses pembentukan cluster perlu adanya teknik agar setiap cluster yang terbentuk memiliki karakteristik yang berbeda dari cluster lainnya berdasarkan variabel pembentuk, salah satunya dengan cara melakukan teknik pengelompokan secara dua arah. Analisis cluster dapat digunakan untuk mengidentifikasi kelompok subjek yang homogen berdasarkan pengukuran kesamaan [16]. Hal yang menjadi perhatian terkait penggunaan pengelompokan satu arah adalah adanya batasan dalam cara mendeteksi kinerja data hanya pada satu sisi. Oleh karena itu, dalam mengatasi hal tersebut penelitian ini menggunakan metode biclustering algoritma CC dalam menentukan daerah pada dimensi variabel rawan pangan. Metode biclustering menghubungkan data yang sesuai dalam pengelompokan secara bersamaan antara provinsi dan karakteristik daerah rawan pangan. Penelitian ini bertujuan untuk mengetahui pola rawan pangan di Indonesia menurut wilayah dan variabel dimensi rawan pangan secara simultan menggunakan analisis biclustering algoritma $\mathrm{CC}$.

\section{Tinjauan Pustaka}

\subsection{Rawan Pangan}

Kerawanan pangan adalah suatu ketidakmampuan mengakses makanan dalam kondisi tertentu, yang dikelompokkan menjadi dua kategori, yaitu kondisi rawan pangan dan tidak rawan pangan [15]. Klasifikasi kerawanan pangan Food Insecurity Experience Scale (FIES) dapat dinyatakan dalam skala ordinal, yaitu tidak rawan, ringan, sedang dan parah. Tingkat kerawanan tersebut didasarkan banyaknya jawaban ya tanpa menghiraukan pengalaman spesifik mana yang diafirmasi [6]. Dalam melakukan pengukuran indikator tujuan kedua SDGs yaitu mengakhiri kelaparan yaitu dengan pendekatan pengukuran rawan pangan dengan menggunakan FIES, dimana rawan pangan dianggap sebagai ketidakmampuan seseorang dalam mengakses pangan dapat dilihat dari pengalaman selama setahun terakhir terhadap kasus rawan pangan [8]. Indikator tersebut yang dijadikan dasar dalam mengukur keberhasilan pemerintah dalam menangani permasalahan kelaparan atau kondisi rawan pangan.

Karakteristik rawan pangan suatu daerah selain diukur menggunakan FIES dapat juga didekati dengan cara menggunakan variabel penjelas yaitu variabel yang berhubungan dengan kemiskinan 


\section{Raditya Novidianto, Rini Irfani Jurnal Matematika, Statistika E Komputasi}

absolut, status rumah tangga pertanian, sumber air minum utama, banyaknya anggota rumah tangga dan persentase pengeluaran untuk makanan [10].

\subsection{Analisis Biclustering}

Bicluster didefinisikan sebagai bagian dari sebuah baris dan bagian dari kolom yang memiliki nilai kesamaan yang tinggi berdasarkan algoritma Cheng dan Church (CC). Tujuan dari algoritma ini adalah untuk menemukan bicluster dengan Mean Square Residual (MSR) lebih kecil dari batas yang ditentukan [11].

Menurut definisi, biclustering mengacu pada algoritma pengelompokan yang melakukan pengelompokan baris dan kolom secara bersamaan. Metode biclustering awalnya diterapkan untuk menganalisis data microarray ekspresi dari gen. Pada 20 tahun terakhir, biclustering telah menjadi populer sehingga tidak hanya di bidang analisis data biologis tetapi juga dalam aplikasi lain dengan dataset dua arah berdimensi tinggi. Teknik ini mengelompokkan baris dan kolom secara bersamaan, bukan hanya mengelompokkan baris atau kolom secara parsial. Biclustering mengambil subgrup objek yang serupa dalam satu subgrup variabel dan berbeda dalam variabel lainnya. Dalam analisis cluster, dapat dituliskan sebagai matriks A dengan ukuran $n \times m$ sebagai berikut [8].

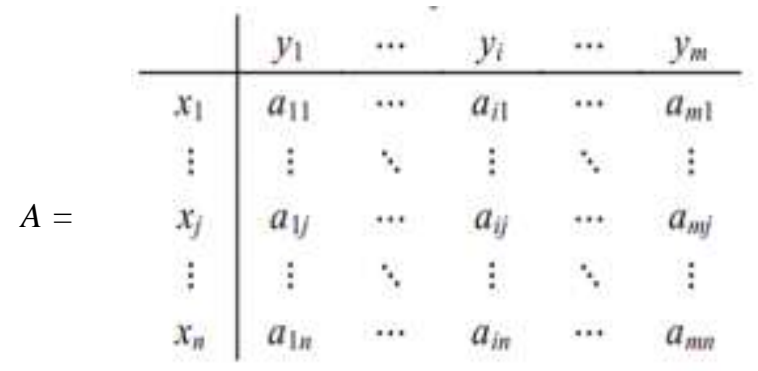

Didefinisikan data dengan matriks Axy, $\mathrm{X}$ sebagai baris dan $\mathrm{Y}$ sebagai kolom. Bicluster disimbolkan dengan sub-matriks (I,J), dengan I $\square$ X dan $\mathrm{J} \square \mathrm{Y}$, dan memiliki nilai MSR di bawah batasan tertentu $(\delta)$, dimana $\delta \geq 0$. Nilai dari $\varepsilon_{i j}$ adalah

$$
\varepsilon_{i j}=a_{i j}-a_{i j}-a_{I j}-a_{I J}
$$

dan nilai MSR adalah:

$$
\operatorname{MSR}(I, J)=\frac{1}{|I||J|} \sum_{i \in I, j \in J}\left(a_{i j}-a_{i J}-a_{I j}+a_{I J}\right)^{2}
$$

dimana $a_{i J}$ adalah rata-rata dari baris ke-i, $a_{I j}$ adalah rata-rata dari baris ke-j dan $a_{I J}$ merupakan rata-rata dari seluruh elemen dalam bicluster.

$$
\begin{gathered}
a_{i J}=\frac{1}{|J|} \sum_{j \in J} a_{i j}, \quad a_{I j}=\frac{1}{|I|} \sum_{i \in I} a_{i j} \\
a_{I J}=\frac{1}{|I||J|} \sum_{i \in I, j \in J} a_{i j}
\end{gathered}
$$




\section{Raditya Novidianto, Rini Irfani Jurnal Matematika, Statistika \& Komputasi}

Dalam algoritma CC, semakin kecil nilai residual maka akan semakin baik kualitas bicluster tersebut, menggunakan rasio dari rata-rata residual terhadap volume untuk membandingkan kualitas bicluster [7]

$$
\frac{1}{n} \sum_{i=1}^{n} \frac{\text { MSR }_{i}}{\text { Volume }_{i}}
$$

\section{Metode Penelitian}

\subsection{Sumber Data dan Variabel Penelitian}

Data yang digunakan dalam penelitian ini merupakan data hasil Survei Sosial Ekonomi Nasional (SUSENAS) dan Survei Angkatan Kerja Nasional (SAKERNAS) yang telah terpublikasikan melalui website resmi BPS. Seleksi variabel dilakukan berdasarkan penelitian terdahulu mengenai rawan pangan baik secara mikro atau makro. Variabel yang digunakan merupakan data cross section di tahun 2019 di Indonesia. Faktor-faktor yang mencirikan status rawan pangan berdasarkan penelitian terdahulu sebagai berikut [10].

Tabel 3.1 Variabel Penelitian

\begin{tabular}{llc}
\hline \multicolumn{1}{c}{ Indikator } & \multicolumn{1}{c}{ Variabel } & Kode \\
\hline \multirow{2}{*}{$\begin{array}{l}\text { Kemiskinan } \\
\text { absolut }\end{array}$} & Persentase kemiskinan & P0 \\
& Indeks kedalaman kemiskinan & P1 \\
Akses terhadap & Gini rasio & P2 \\
keuangan & Persentase pengeluaran makanan & $\mathrm{X} 1$ \\
\hline \multirow{2}{*}{$\begin{array}{l}\text { Status kesehatan } \\
\text { Nemografi }\end{array}$} & Persentase penduduk konsumsi kalori dibawah 1400 KKAL & $\mathrm{X} 2$ \\
\hline Angka Harapan Hidup (AHH) & $\mathrm{X} 3$ \\
\hline $\begin{array}{l}\text { Karakteristik } \\
\text { perumahan }\end{array}$ & Banyaknya anggota rumah tangga & $\mathrm{X} 4$ \\
\hline Ketenagakerjaan & Pependensi rasio & $\mathrm{X} 5$ \\
\hline
\end{tabular}

\subsection{Langkah Analisis}

Penelitian ini menggunakan bantuan software R-4.0.3 for Windows 64 bit dalam menentukan cluster dan Microsoft Excel untuk menghitung MSR/V. Berikut merupakan langkah-langkah pengelompokan provinsi di Indonesia berdasarkan variabel penciri rawan pangan

1. Melakukan eksplorasi dan scaling data terhadap data awal sehingga dapat diketahui gambaran deskriptif mengenai karakteristik pola hubungan antar variabel penciri rawan pangan di Indonesia tahun 2019. 


\section{Raditya Novidianto, Rini Irfani Jurnal Matematika, Statistika E Komputasi}

2. Menghitung MSR/V pada setiap cluster yang terbentuk pada bicluster hasil algoritma CC.

3. Menentukan bicluster berdasarkan algoritma $\mathrm{CC}$ dengan melakukan tuning parameter $\delta$ (gamma).

4. Memilih bicluster terbaik dengan melihat dari MSR/V yang paling kecil dan profiling model terbaik bicluster.

5. Menarik kesimpulan dan saran berdasarkan bicluster terbaik untuk mitigasi kebijakan penanggulangan rawan pangan masa pandemi COVID-19.

\section{Hasil dan Pembahasan}

\subsection{Statistik Deskriptif}

Pada tahapan ini dilakukan proses scaling dengan menggunakan rumus standardization dengan rata-rata 0 dan standard deviasi 1 untuk menghilangkan efek satuan yang berbeda-beda dalam penggunaan variabel. Proses ini merupakan suatu teknik pendekatan dalam analisis peubah ganda yang berupaya untuk memvisualisasikan kemiripan atau ketidakmiripan antara objek dalam bentuk warna berdimensi dua. Dalam penelitian dilakukan penyajian statistik deskriptif secara visual untuk melihat keterkaitan antar variabel untuk menggambarkan variabel penciri rawan pangan di Indonesia secara umum. Pola hubungan tersebut digunakan dasar dalam pembentukan bicluster secara visual dengan menggunakan heatmap, sehingga bisa diketahui signal dari setiap variabel menunjukkan kekuatannya secara visual.

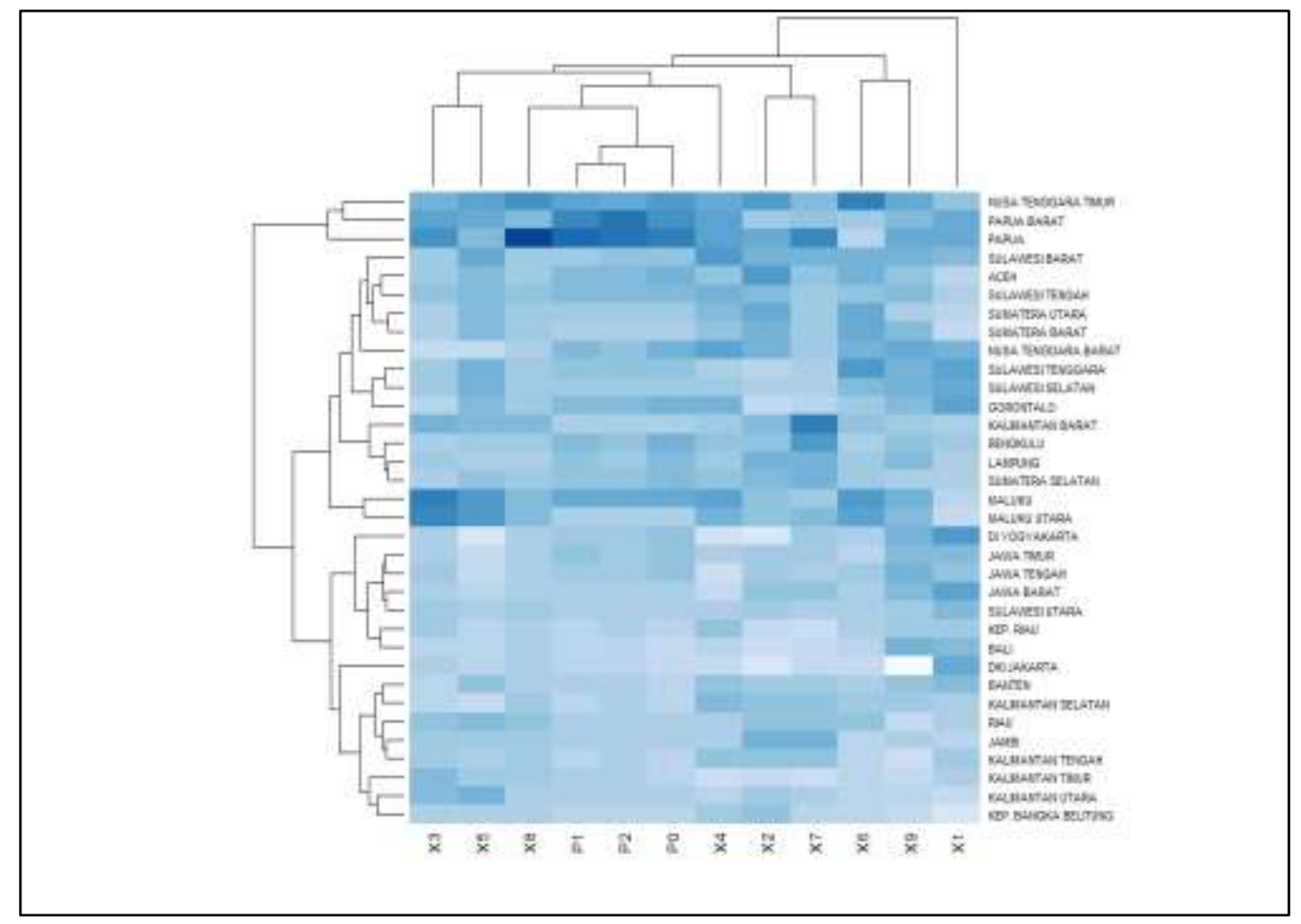

Gambar 4.1 Heatmap variabel penciri rawan pangan di Indonesia

Gambar di atas menunjukkan heatmap variabel penciri rawan pangan secara visual antara variabel dan objek berdasarkan nilai korelasi menggunakan dendrogram. Provinsi atau variabel yang mempunyai korelasi akan dimasukkan kedalam satu grup. Dari heatmap di atas menunjukkan bahwa terdapat dua kelompok besar yaitu variabel persentase kemiskinan (P0), indeks kedalaman kemiskinan (P1), indeks keparahan kemiskinan (P2) dan persentase sumber penerangan tidak menggunakan listrik (X8) merupakan kelompok pertama, selebihnya yaitu merupakan variabel kelompok kedua. Heatmap juga menunjukkan bahwa cell yang lebih gelap menujukkan area 


\section{Raditya Novidianto, Rini Irfani Jurnal Matematika, Statistika E Komputasi}

dengan nilai variabel yang tinggi, sehingga daerah di atas merupakan nilai variabel dengan nilai tinggi sebagai penciri rawan pangan dan kelompok bawah yang memiliki warna lebih cerah memiliki nilai variabel rawan pangan yang rendah.

\subsection{Analisis Bicluster}

Analisis bicluster memiliki pendekatan yaitu dengan cara menjalankan algoritma di beberapa parameter dan dilakulan dengan tuning secara manual. Nilai rata-rata MSR/V yang terkecil hasil analisis bicluster merupakan hasil pengelompokan objek terbaik. Dalam algoritma CC akan menghasilkan bicluster yang sebesar mungkin dengan nilai MSR yang rendah, sehingga parameter terbaik yaitu menghasilkan nilai MSR/V terkecil.

Tabel 4.1 Hasil penyetelan parameter (Tuning Parameter)

\begin{tabular}{ccc}
\hline $\boldsymbol{\delta}$ & Jumlah Bicluster & MSR/V \\
\hline 0,1 & 5 & 0,01737 \\
0,2 & 3 & 0,02258 \\
0,3 & 3 & 0,01790 \\
0,4 & 2 & 0,02451 \\
0,5 & 1 & 0,00000 \\
0,6 & 1 & 0,00000 \\
0,7 & 1 & 0,00000 \\
0,8 & 1 & 0,00000 \\
0,9 & 1 & 0,00000 \\
1 & 1 & 0,00000 \\
\hline
\end{tabular}

Tabel 4.1 menujukkan bahwa tidak terdapat hubungan linear antara tuning parameter dengan hasil MSR/V dari biscluster. Pada tuning parameter dengan $\delta$ lebih dari 0,5 maka cluster yang terbentuk hanya satu dan memiliki MSR/V sebesar nol, sehingga tidak memiliki arti. Sehingga dalam pemilihan parameter sebaiknya memilih parameter yang membentuk bicluster minimal dua. Bentuk bicluster yang terbaik yaitu yang memiliki nilai MSR/V terkecil yaitu pada tuning parameter $\delta$ sama dengan 0,1 dengan nilai MSR/V yaitu sebesar 0,01737 dengan membentuk bicluster sebanyak 5 dengan rincian sebagai berikut

Tabel 4.2 Banyaknya provinsi dan variabel dari bicluster terbaik

\begin{tabular}{ccc}
\hline Bicluster & Banyaknya Provinsi & Banyaknya Variabel \\
\hline 1 & 15 & 8 \\
2 & 10 & 5 \\
3 & 3 & 7 \\
4 & 4 & 4 \\
5 & 2 & 9 \\
\hline
\end{tabular}

Tabel 4.2 menunjukkan banyaknya bicluster terbaik yaitu pada bicluster 1 adalah sebanyak 15 provinsi dan 8 variabel pembentuk, bicluster 2 terdapat 10 provinsi dengan 5 variabel pembentuk, bicluster 3 terdapat 3 provinsi dengan 7 variabel pembentuk, bicluster 4 terdapat 4 provinsi dan 4 variabel pembentuk dan bicluster 5 terdapat 2 provinsi dengan 9 variabel pembentuk. Dalam pembentukan bicluster dimungkinkan untuk terdapat variabel yang beririsan antar bicluster dan memungkinkan juga terdapat objek atau provinsi yang bisa tidak terkategori dalam bicluster, namun pada bicluster dengan $\delta=0,1$ semua provinsi masuk ke dalam masing-masing bicluster yang ada. 
Raditya Novidianto, Rini Irfani

\section{Jurnal Matematika, Statistika \& Komputasi}

Tabel 4.3 Rincian setiap anggota bicluster

\begin{tabular}{|c|c|c|c|c|}
\hline Bicluster 1 & Bicluster 2 & Bicluster 3 & Bicluster 4 & Bicluster 5 \\
\hline $\begin{array}{c}\text { Variabel: } \\
\text { P0 P1 P2 X2 X3 X4 } \\
\text { X7 X8 }\end{array}$ & $\begin{array}{c}\text { Variabel: } \\
\text { P0 P1 P2 X7 X9 }\end{array}$ & $\begin{array}{l}\text { Variabel: } \\
\text { P0 P1 P2 } \\
\text { X3 X5 X6 } \\
\text { X8 }\end{array}$ & $\begin{array}{c}\text { Variabel: } \\
\text { P0 P1 P2 X3 }\end{array}$ & $\begin{array}{c}\text { Variabel: } \\
\text { P0 P1 P2 X2 } \\
\text { X4 X6 X7 X8 } \\
\text { X9 }\end{array}$ \\
\hline $\begin{array}{l}\text { Sumatera Utara, } \\
\text { Sumatera Barat, Riau, } \\
\text { Jambi, Sumatera } \\
\text { Selatan, Lampung, } \\
\text { Kep. Bangka Belitung, } \\
\text { Jawa Barat, Jawa } \\
\text { Timur, Banten, } \\
\text { Kalimantan Tengah, } \\
\text { Kalimantan Selatan, } \\
\text { Sulawesi Utara, } \\
\text { Sulawesi Tengah, } \\
\text { Sulawesi Selatan }\end{array}$ & $\begin{array}{l}\text { Aceh, Kep. Riau, } \\
\text { Jawa Tengah, } \\
\text { Nusa Tenggara } \\
\text { Barat, Nusa } \\
\text { Tenggara Timur, } \\
\text { Kalimantan } \\
\text { Timur, } \\
\text { Kalimantan } \\
\text { Utara, Sulawesi } \\
\text { Tenggara, } \\
\text { Gorontalo, } \\
\text { Maluku }\end{array}$ & $\begin{array}{l}\text { DKI } \\
\text { Jakarta, } \\
\text { Bali, } \\
\text { Kalimantan } \\
\text { Barat }\end{array}$ & $\begin{array}{l}\text { Bengkulu, DI } \\
\text { Yogyakarta, } \\
\text { Papua Barat, } \\
\text { Papua }\end{array}$ & $\begin{array}{l}\text { Sulawesi } \\
\text { Barat, } \\
\text { Maluku Utara }\end{array}$ \\
\hline
\end{tabular}

Tabel 4.3 menunjukkan rangkuman pembentukan bicluster berdasarkan perhitungan kemiripan karakteristik dari variabel rawan pangan dan provinsi di Indonesia. Proses visualisasi pembentukan bicluster terdapat pada lampiran 2, dimana terdapat kemiripan variabel kerawanan pangan dan provinsi dijadikan kelompok tersendiri. Parallel coordinate pada lampiran 3 hingga lampiran 7 digunakan untuk memeriksa hasil bicluster yang terbentuk berdasarkan variabel rawan pangan dan provinsi, dimana tidak terlihat adanya nilai ekstrem didalamnya. Hal yang menarik terdapat pada bicluster 5 terdapat variabel rawan pangan yang dominan kecuali variabel X1, X3 dan X5.

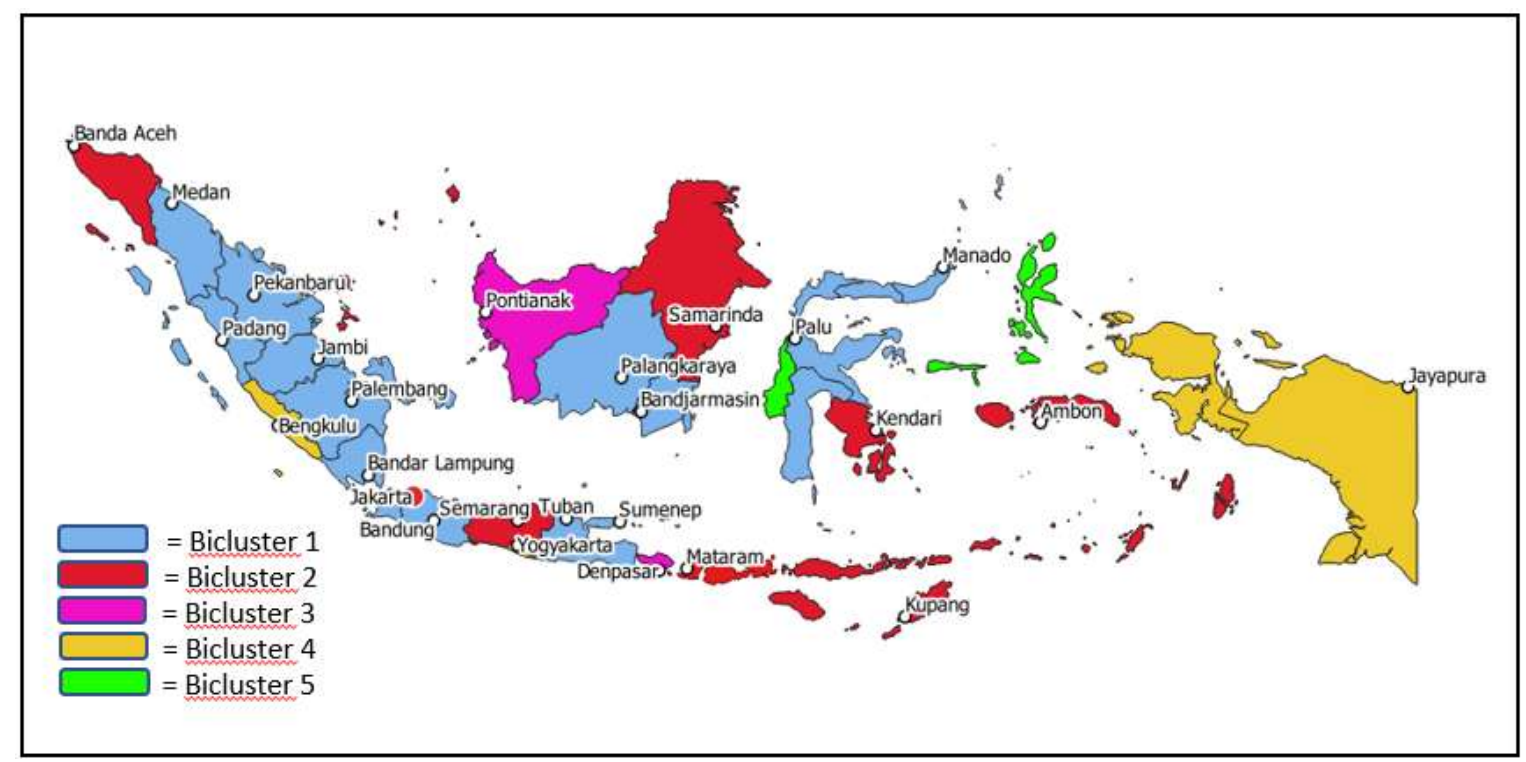

Gambar 4.2 Peta bicluster rawan pangan di Indonesia

Gambar 4.2 menggambarkan secara visual bicluster menjadi beberapa warna yang menunjukkan karakteristik bicluster berdasarkan variabel rawan pangan. Indikator ketahanan dan kerentanan pangan dihitung berdasarkan variabel Food Security and Vulneralbilty Atlas (FSVA) 


\section{Raditya Novidianto, Rini Irfani Jurnal Matematika, Statistika \& Komputasi}

bahwa daerah Papua dan Papua Barat memiliki daerah dengan tingat rawan pangan yang tinggi [1]. Hal ini sejalan dengan penelitian yang menunjukkan wilayah Papua dan Papua barat berada satu bicluster yaitu bicluster 4, sedangkan Provinsi Bengkulu dan DI Yogyakarta terkategori karena didapatkan kemiskinan absolut dan konsumsi pangan di bawah 1400 KKAL yang tinggi dibanding daerah dalam satu pulau. Pulau Sumatera menunjukkan dominasinya mengikuti bicluster 1, kecuali Provinsi Aceh dan Bengkulu berada pada bilcuster 2 dan bicluster 4. Pulau Jawa dari 6 provinsi terdapat 3 diantaranya terdapat pada bicluster 1, selebihnya Jawa tengah, DKI Jakarta dan DI Yogyakarta berada pada bicluster 2, bicluster 3 dan bicluster 4. Pulau Kalimantan merupakan satusatunya pulau yang memiliki karakteristik rawan pangannya berbeda-beda seperti gambar di atas. Pulau Sulawesi yang memiliki dominan berada pada bicluster 1 kecuali Provinsi Sulawesi Barat dan Provinsi Sulawesi Tenggara yang berada pada bicluster 5 dan bicluster 2. Wilayah kepulauan Bali, Nusa Tenggara dan Maluku cenderung berada pada bicluster 2 kecuali Maluku Utara yang berada pada bicluster 5 .

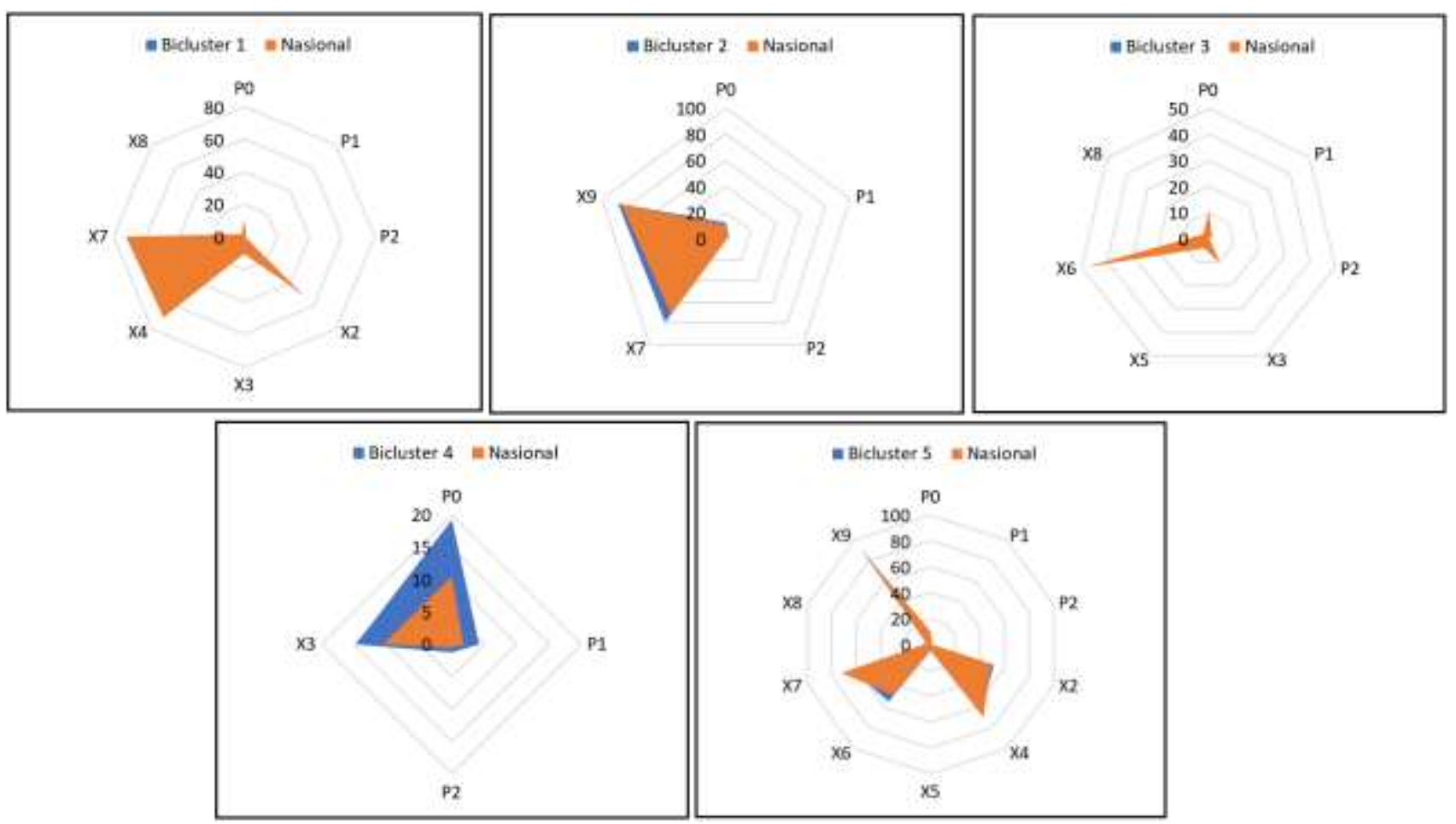

Gambar 4.3 Radar chart bicluster (1, 2, 3, 4 dan 5) dan Nasional

Gambar di atas berdasarkan pada lampiran 1, gambaran data setelah terbentuk bicluster menunjukkan bahwa bicluster 1 berisikan 15 provinsi dan 8 variabel pembentuk dengan rata-rata variabel mendekati angka nasional maka bicluster 1 merupakan representasi dari kondisi nasional. Dalam pemilihan variabel diketahui bahwa semakin besar nilai variabel maka semakin mendekati kondisi rawan pangan sehingga pada bicluster 3 berisikan 3 provinsi dengan 7 variabel pembentuk nilai variabel didalamnya memiliki nilai yang jauh di bawah angka nasional sehingga merupakan daerah yang memiliki kondisi rawan pangan dengan resiko rendah. Bicluster 2 dan bicluster 5 jika dalam radar chart terlihat masih terdapat rata-rata variabel yang berada diatas nasional, misalnya variabel P0 dan P1 pada bicluster 2 serta variabel X6 dan X8 pada bicluster 5. Bicluster 4 berisikan 4 provinsi dan 4 variabel pembentuk dengan rata-rata di atas nasional, hal ini sejalan dengan penelitian sebelumnya yang menyatakan bahwa variabel penciri tingkat kerawanan pangan diantaranya adalah variabel kemiskinan. 


\section{Raditya Novidianto, Rini Irfani Jurnal Matematika, Statistika \& Komputasi}

\section{Kesimpulan dan Saran}

Berdasarkan hasil analisis, diperoleh beberapa kesimpulan dari penelitian ini yaitu

1. Hasil penelitian menunjukkan bahwa dengan menggunakan algoritma $\mathrm{CC}$ terbentuk 5 bicluster dari variabel penciri rawan pangan di Indonesia.

2. Setiap provinsi dalam bicluster yang terbentuk memiliki karakteristik yang berbeda-beda, sehingga perlunya penanganan rawan pangan berdasarkan karakteristik kesamaan daerah dengan daerah lainnya.

3. Variabel pada bicluster empat merupakan bicluster yang memiliki nilai variabel di atas rata-rata nasional, sehingga perlu perhatian khusus dalam penanganan rawan pangan.

4. Variabel P0, P1 dan P2 merupakan variabel kemiskinan absolut yang muncul di setiap cluster sebagai pola penentu terbentuknya bicluster rawan pangan, sehingga perlunya kebijakan yang berhubungan dengan kemiskinan absolut seperti bantuan sosial sehingga rawan pangan dapat terkendali di masa Pandemi Covid-19.

Berdasarkan penelitian diatas didapatkan saran sebagai berikut

1. Perbedaan karakteristik merupakan rujukan kepada pemerintah untuk memperhatikan kebijakan yang bersifat spasial berdasarkan similarity daerah berdasarkan variabel penciri rawan pangan khususnya pada saat pandemi COVID-19 berlangsung dan tidak semua daerah dianggap sama penanganannya.

2. Perlunya penelitian lanjutan untuk mendeteksi rawan pangan ketingkat kabupaten/kota guna melihat efek spasial dalam penangganan rawan pangan yang berada di daerah pada masa pandemi COVID-19.

3. Perlunya instrumen khusus berdasarkan variabel penciri kepada daerah yang terkelompok pada cluster dengan nilai variabel di atas nasional untuk menjadi prioritas utama.

\section{Daftar Pustaka}

[1] Badan Ketahanan Pangan. 2019. Peta Ketahanan Pangan (Food Security and Vulnerability Atlas). Publikasi. Kementerian Pertanian. Jakarta. Sumber: http://bkp.pertanian.go.id/

[2] Badan Pusat Statistik. 2016. Potret Awal Tujuan Pembangunan Berkelanjutan (Sustainable Development Goals) di Indonesia. Jakarta. Sumber: www.bps.go.id/publication/

[3] Badan Pusat Statistik. 2019. Indikator Tujuan Pembangunan Berkelanjutan (TPB) Indonesia. Jakarta. Sumber: https://www.bps.go.id/indicator.

[4] Badan Pusat Statistik. 2020. BRS Pertumbuhan Ekonomi Indonesia Triwulan III-2020. Jakarta. Sumber: https://www.bps.go.id/pressrelease/2020/11/05/1738/ ekonomi-indonesiatriwulan-iii-2020-tumbuh-5-05-persen--q-to-q-.html.

[5] Badan Pusat Statistik. 2020. BRS Profil Kemiskinan Di Indonesia Maret 2020. Jakarta. Sumber: https://www.bps.go.id/pressrelease/2020/07/15/1744/persentase-penduduk-miskinmaret-2020-naik-menjadi-9-78-persen.html.

[6] Cafiero, C., Viviani, S. and Nord, M., 2018. Food security measurement in a global context: The food insecurity experience scale. Measurement, 116, pp.146-152.

[7] Chakraborty, A. and Maka, H. 2005. Biclustering of gene expression data using genetic algorithm. In 2005 IEEE Symposium on Computational Intelligence in Bioinformatics and Computational Biology (pp. 1-8). IEEE.

[8] Frongillo, E.A., Nguyen, H.T., Smith, M.D. and Coleman-Jensen, A., 2019. Food Insecurity Is 


\section{Raditya Novidianto, Rini Irfani Jurnal Matematika, Statistika E Komputasi}

More Strongly Associated with Poor Subjective Well-Being in More-Developed Countries than in Less-Developed Countries. The Journal of Nutrition, 149(2), pp.330-335.

[9] Gundersen, C. and Ziliak, J.P., 2015. Food insecurity and health outcomes. Health affairs, 34(11), pp.1830-1839.

[10] Irawan, Heru. 2019. Faktor-Faktor Rumah Tangga Yang Mencirikan Tingkat Kerawanan Pangan. Thesis. IPB University. Bogor. Sumber : https://repository.ipb.ac.id/

[11] Kaban, Puspita Anggraini, Robert Kurniawan, Rezzy Eko Caraka, Bens Pardamean, and Budi Yuniarto. 2019. Biclustering Method to Capture the Spatial Pattern and to Identify the Causes of Social Vulnerability in Indonesia: A New Recommendation for Disaster Mitigation Policy. Procedia Computer Science 157:31-37.

[12] Kaiser, S., 2011. Biclustering: methods, software and application. Doctoral dissertation. Universitas Ludwig Maximilian. Munich.

[13] Lailatusysyukriyah, L. 2015. Indonesia dan Konsepsi Negara Agraris. Junrnal Seuneubok Lada 2(1):1-8. Universitas Samudra. Langsa.

[14] Paslakis, Georgios, Gina Dimitropoulos, and Debra K. Katzman. 2020. A Call to Action to Address COVID-19-Induced Global Food Insecurity to Prevent Hunger, Malnutrition, and Eating Pathology. Nutrition Reviews. Sumber : https://doi: 10.1093/nutrit/nuaa069

[15] Purwantini, Tri Bastuti. 2016. Pendekatan Rawan Pangan Dan Gizi: Besaran, Karakteristik, Dan Penyebabnya. Jurnal Kementerian Pertanian Republik Indonesia. Jakarta. Sumber : https://repository.pertanian.go.id

[16] Putri, Christiana Anggraeni dan Rini Irfani. 2020. Recognizing Poverty Pattern In Central Java Using Biclustering Analysis. International Conference On Mathematics, Statistics and Data Science (ICMSDS). IPB University. Bogor.

[17] Smith, Michael D., Woubet Kassa, and Paul Winters. 2017. Assessing Food Insecurity in Latin America and the Caribbean Using FAO's Food Insecurity Experience Scale. Food Policy 71:48-61.

[18] Yuniarto, Budi, and Robert Kurniawan. 2017. Understanding Structure of Poverty Dimensions in East Java: Bicluster Approach. Signifikan: Jurnal Ilmu Ekonomi 6(2):289300 .

\section{LAMPIRAN}

Lampiran 1 Rata-rata dan standard deviasi antar bicluster dan Nasional

\begin{tabular}{|c|c|c|c|c|c|c|c|c|c|c|c|c|}
\hline \multirow{2}{*}{ Variabel } & \multicolumn{2}{|c|}{ Bicluster 1} & \multicolumn{2}{|c|}{ Bicluster 2} & \multicolumn{2}{|c|}{ Bicluster 3} & \multicolumn{2}{|c|}{ Bicluster 4} & \multicolumn{2}{|c|}{ Bicluster 5} & \multicolumn{2}{|c|}{ Nasional } \\
\hline & $\begin{array}{c}\text { Rata- } \\
\text { rata }\end{array}$ & Stdev & $\begin{array}{c}\text { Rata- } \\
\text { rata }\end{array}$ & Stdev & $\begin{array}{c}\text { Rata- } \\
\text { rata }\end{array}$ & Stdev & $\begin{array}{c}\text { Rata- } \\
\text { rata }\end{array}$ & Stdev & $\begin{array}{c}\text { Rata- } \\
\text { rata }\end{array}$ & Stdev & $\begin{array}{c}\text { Rata- } \\
\text { rata }\end{array}$ & Stdev \\
\hline P0 & 8.11 & 3.00 & 12.47 & 5.24 & 4.92 & 2.23 & 19.16 & 3.01 & 8.90 & 3.01 & 10.46 & 5.68 \\
\hline $\mathbf{P 1}$ & 1.28 & 0.55 & 2.16 & 1.10 & 0.72 & 0.36 & 4.25 & 0.61 & 1.32 & 0.61 & 1.84 & 1.44 \\
\hline $\mathbf{P 2}$ & 0.32 & 0.16 & 0.56 & 0.31 & 0.15 & 0.07 & 1.29 & 0.19 & 0.35 & 0.19 & 0.49 & 0.47 \\
\hline $\mathrm{X} 2$ & 50.68 & 1.73 & & & & & & & 51.54 & 2.01 & 49.69 & 3.83 \\
\hline X3 & 7.98 & 2.07 & & & 8.36 & 6.04 & 14.77 & 12.91 & & & 10.48 & 6.52 \\
\hline $\mathrm{X} 4$ & 70.25 & 1.26 & & & & & & & 66.50 & 2.38 & 69.89 & 2.55 \\
\hline X5 & & & .1 & & 3.97 & 0.29 & .0 & & & & 4.10 & 0.35 \\
\hline X6 & 0.01 & & 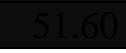 & & 45.00 & 4.12 & & & 54.90 & 1.56 & 48.93 & 5.12 \\
\hline$X 7$ & 72.37 & 6.81 & 79.04 & 8.78 & & & & & 64.19 & 0.90 & 72.14 & 12.69 \\
\hline $\mathrm{X} 8$ & 1.04 & 1.02 & & & 1.79 & 2.98 & & & 3.23 & 1.77 & 2.51 & 5.19 \\
\hline X9 & & & 87.09 & 9.12 & & & 925 & & 92.64 & 1.00 & 84.55 & 11.73 \\
\hline
\end{tabular}


Raditya Novidianto, Rini Irfani

Jurnal Matematika, Statistika \& Komputasi

Lampiran 2. Grafik pembentuk cluster bantuan software R-4.0.3 for Windows 64 bit

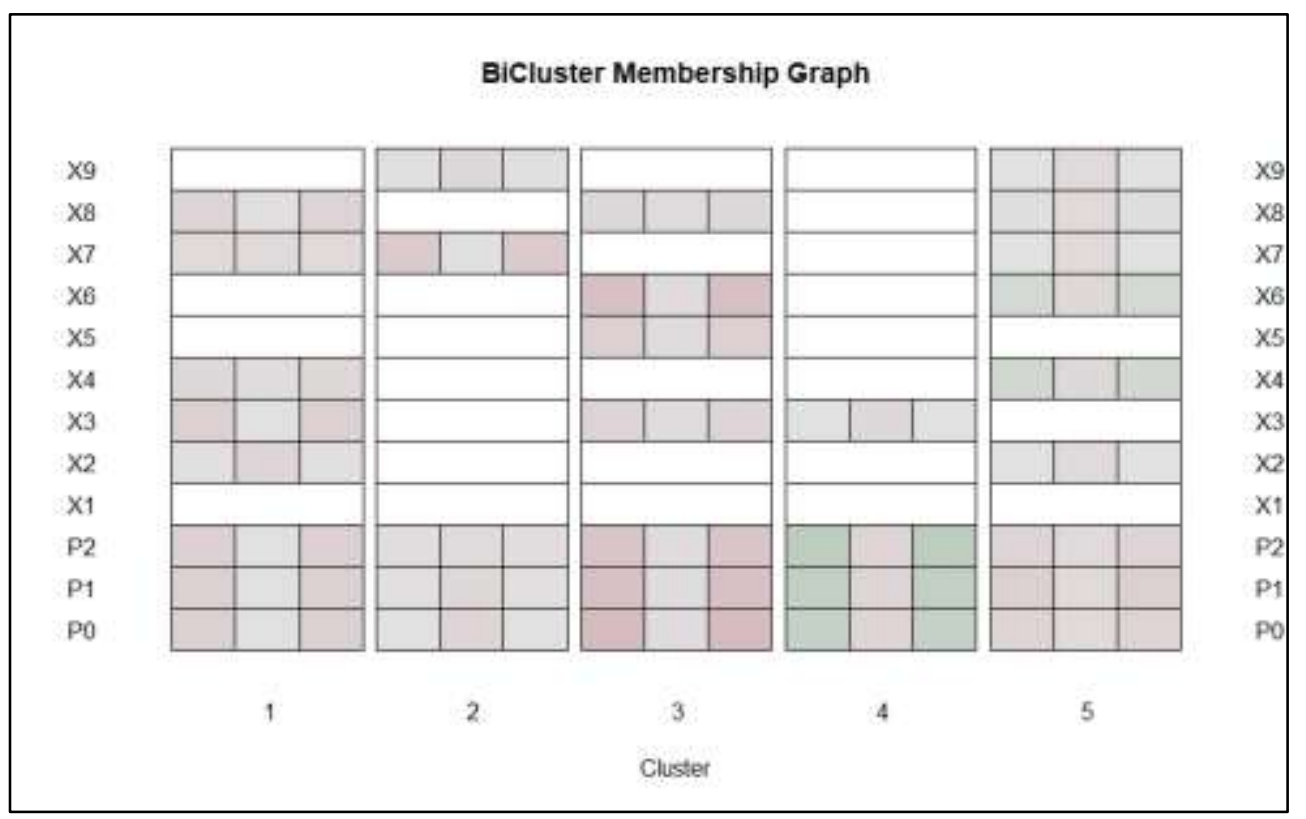

Lampiran 3 Parallel coordinate Bicluster 1

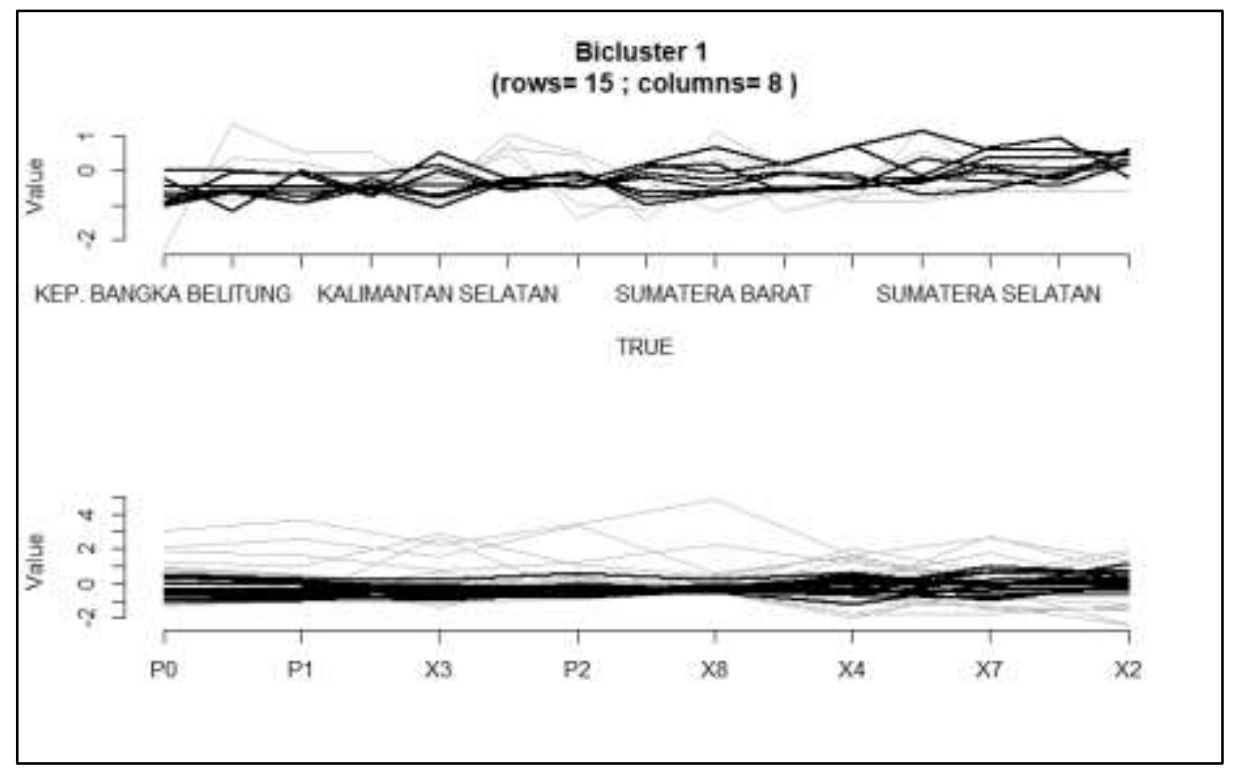


Raditya Novidianto, Rini Irfani

\section{Jurnal Matematika, Statistika E Komputasi}

Lampiran 4 Parallel coordinate Bicluster 2

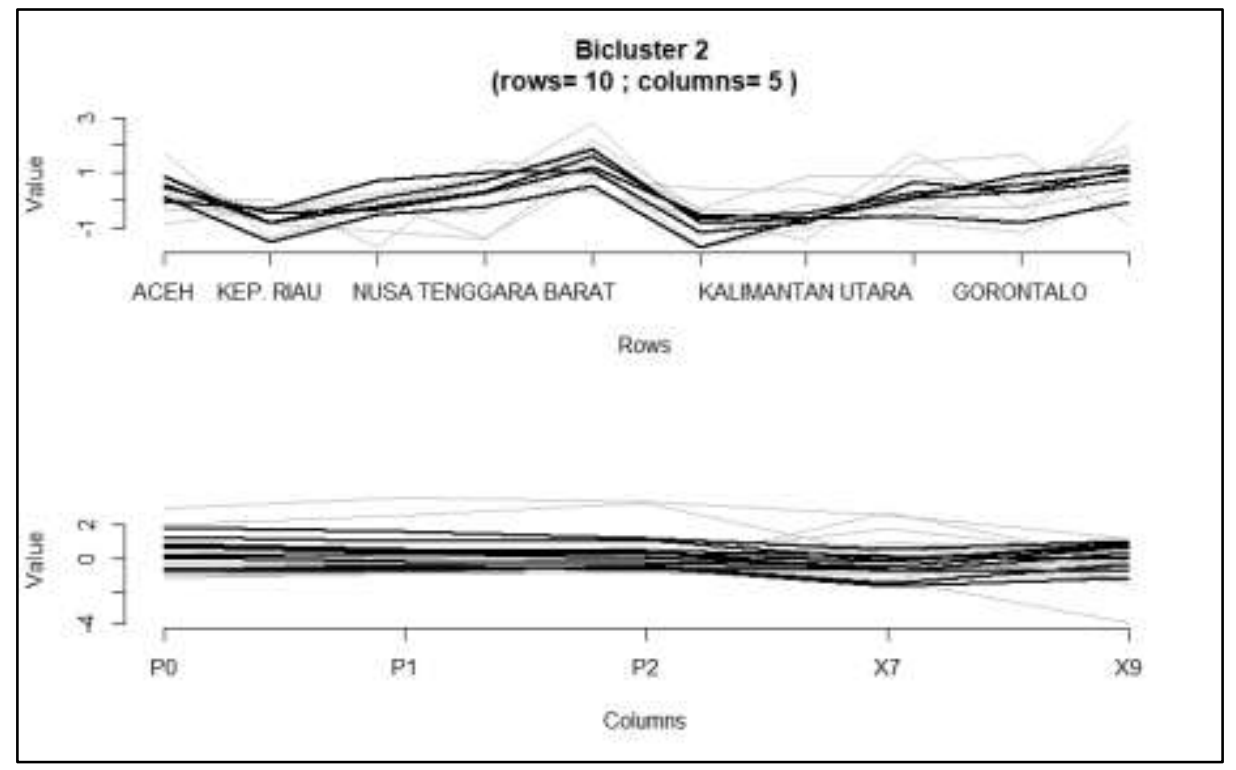

Lampiran 5 Parallel coordinate Bicluster 3

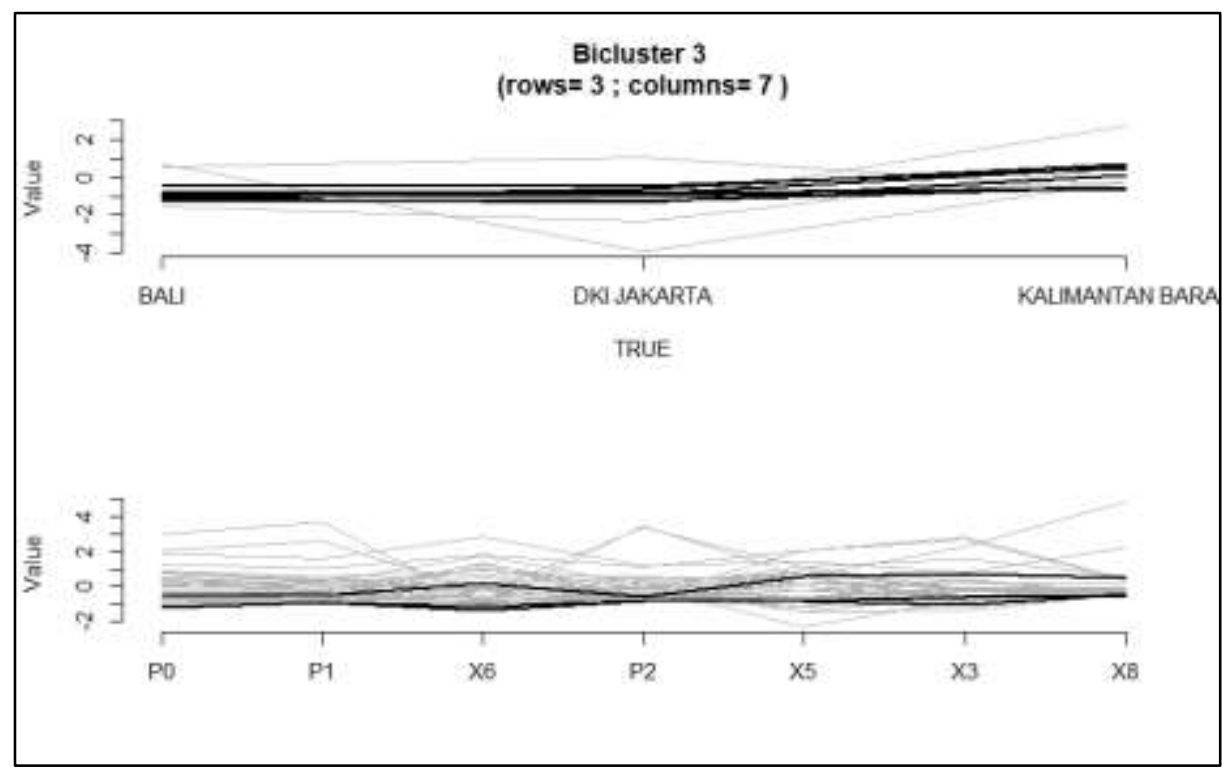


Raditya Novidianto, Rini Irfani

\section{Jurnal Matematika, Statistika \& Komputasi}

Lampiran 6 Parallel coordinate Bicluster 4

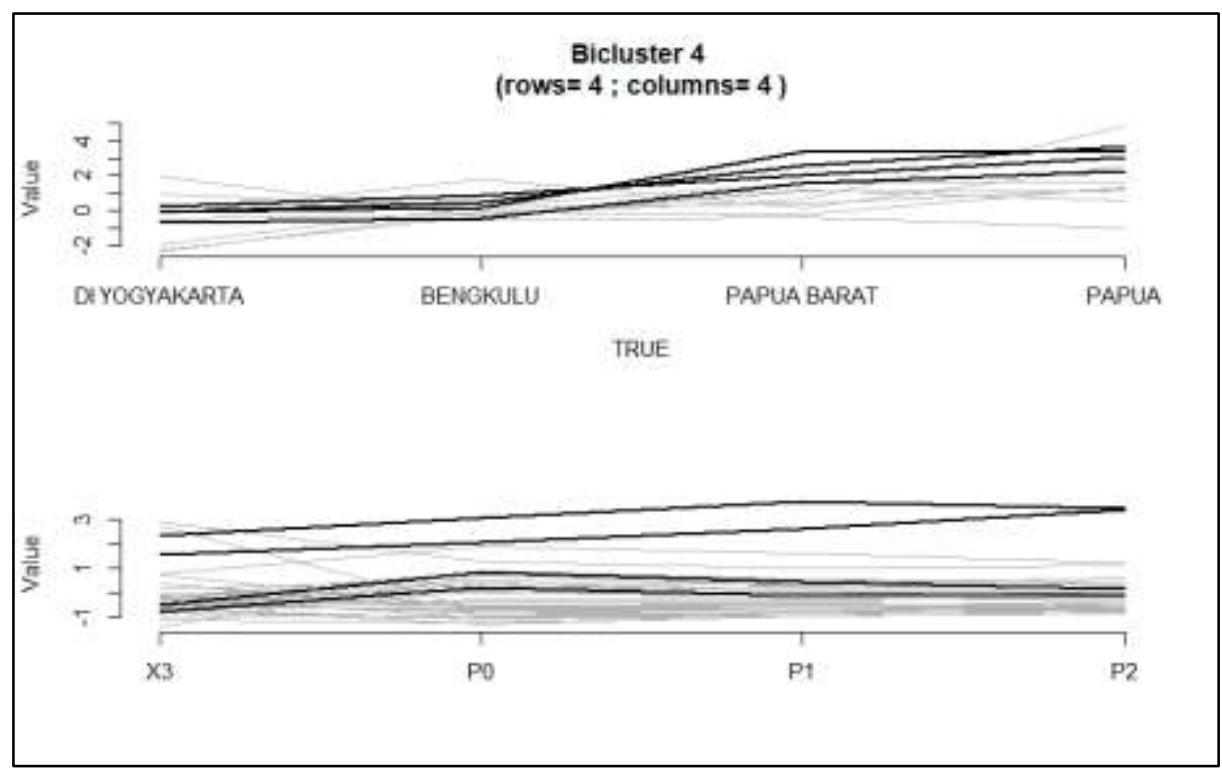

Lampiran 7 Parallel coordinate Bicluster 5

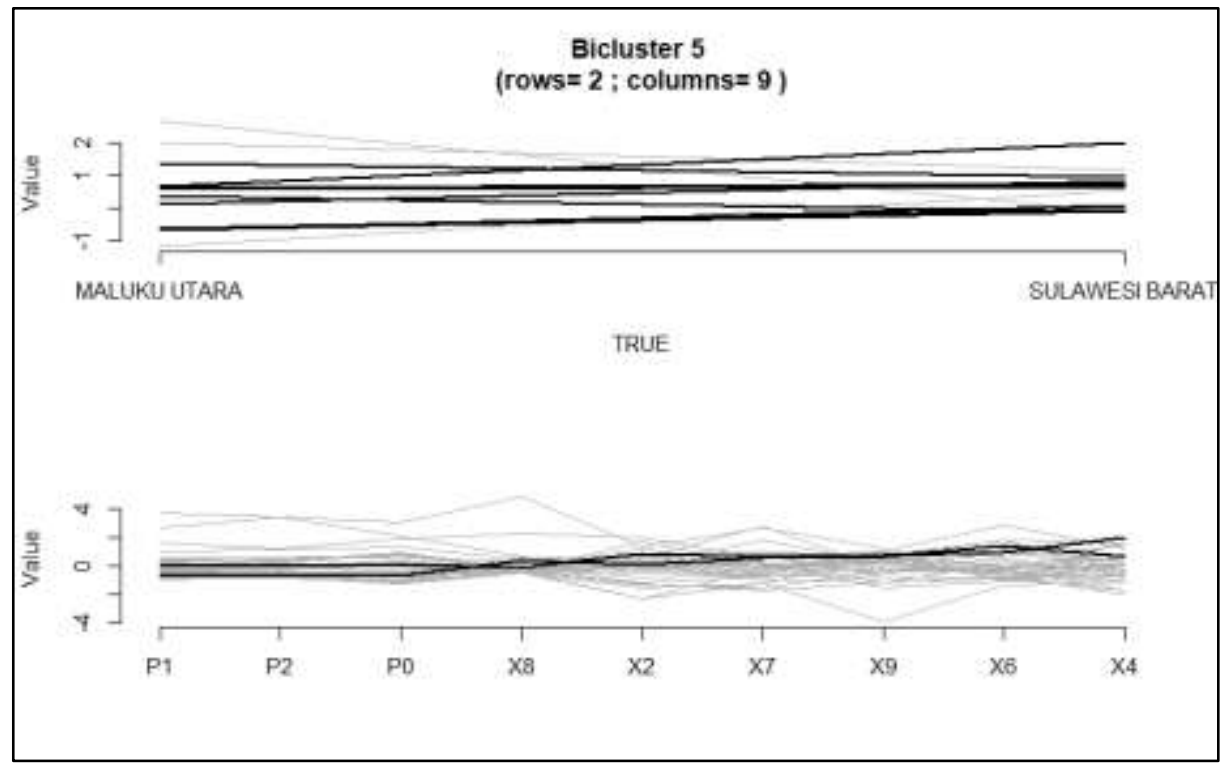

